\title{
Traumatic orbital fracture with intact ocular globe displacement into the maxillary sinus
}

Fratura traumática de órbita com deslocamento de globo ocular intacto para o seio maxilar

Nadyr Antônia Pereira Damasceno', Eduardo de França Damasceno²

\begin{abstract}
The authors report one case of orbital fracture of the floor and the medial walls after trauma with an intact ocular globe displacement into the maxillary sinus. The same authors emphasize the treatment, complications and the rarity of this case.

In this case the patient developed a good visual acuity and a loss of ocular motility as complication (except abduction).
\end{abstract}

Keywords: Orbital fracture/complications; Eye injuries/complications; Case reports

\footnotetext{
${ }^{1}$ Medical Staff - Ophthalmology Service - Hospital Municipal Souza Aguiar - Rio de Janeiro - RJ - Brazil;

${ }^{2}$ Medical Staff - Ophthalmology Department - Hospital Universitário Clementino Fraga Filho UFRJ - Rio de Janeiro - RJ - Brazil.

Instituição: Hospital Municipal Souza Aguiar - Rio de Janeiro (RJ), Brasil

Recebido para publicação em: 14/10/2008 - Aceito para publicação em 8/11/2009
} 


\section{INTRODUCTION}

A mong the main types of fractures of the or bital wall, there is the floor fracture that can cause herniation of orbital anatomical structures such as the inferior rectus muscle, the inferior oblique muscle and, sometimes, the periorbital fat. This results in an immediate deficit of muscular motility and ocular pain, mainly in up-gaze, and in diplopia that follows this movement ${ }^{(1)}$. The ischemia of these structures happens rapidly, and this fracture constitutes a therapeutic urgency, needing surgical approach in up to 48 hours. The diagnosis is based on clinical features and imaging studies ${ }^{(1,2)}$. It is very important to do a computerized scan and, sometimes, MRI (Magnetic Resonance Imaging) because simple $\mathrm{X}$ - rays do not allow seeing soft- tissue structures in detail ${ }^{(1,3,4)}$. Less common than the floor fracture is the orbital medial wall fracture, with lesion of the lamina papiracea which, in that case, makes an otorhinolaryngological and craniofacial intervention necessary. The reconstructive procedure uses a titanium plate or a polypropylene plate to support the structures ${ }^{(5)}$. In this study, we report a rare fact described in medical literature, which is the traumatic displacement of an intact ocular globe into the maxillary sinus, with good visual acuity after treatment.

\section{Case related}

A 42- year- old man, born in Rio de Janeiro, who works as a longshoreman, suffered a contusion on the right orbit. The patient presented an intense swelling of the right eyelid and pain, which avoided the ocular examination. The computerized tomography (CT) of the orbit showed a fracture of the floor and medial wall, with a complete displacement of the right ocular globe into the maxillary sinus (figure 1 ).

The patient was immediately admitted to the operating room and underwent a reduction of the ocular globe through the naso- maxillary space as well as a metallic plate implantation on the orbital floor through a lateral canthotomy and opening of the inferior forniceal conjunctiva. The procedure was done under general anesthesia by a craniofacial surgeon and ophthalmologist together.A review of the four rectus muscles was done to observe their integrity.

The patient presented, 48 hours after surgery, a visual acuity of 20160 in the right eye and 20120 in the left eye. Under slit-lamp examination, epithelial keratitis in the right eye, moderate blepharoedema, conjunctival hyperemia and partial limitation of the ocular globe motility were observed. The intraocular pressure (IOP) was $18 \mathrm{mmhg}$ (RE) and $13 \mathrm{mmhg}$ (LE).

Ten days after surgery, the patient was submitted to a new $\mathrm{CT}$ of the orbit revealing a metallic plate on the floor, the ocular globe in an anatomical position and extra ocular muscles with a partial edema.

The patient evolved into a loss of ocular motility (except for abduction), diplopia, visual, acuity of 20120, preserved visual field and normal pupillary reflex to light (figure 2).
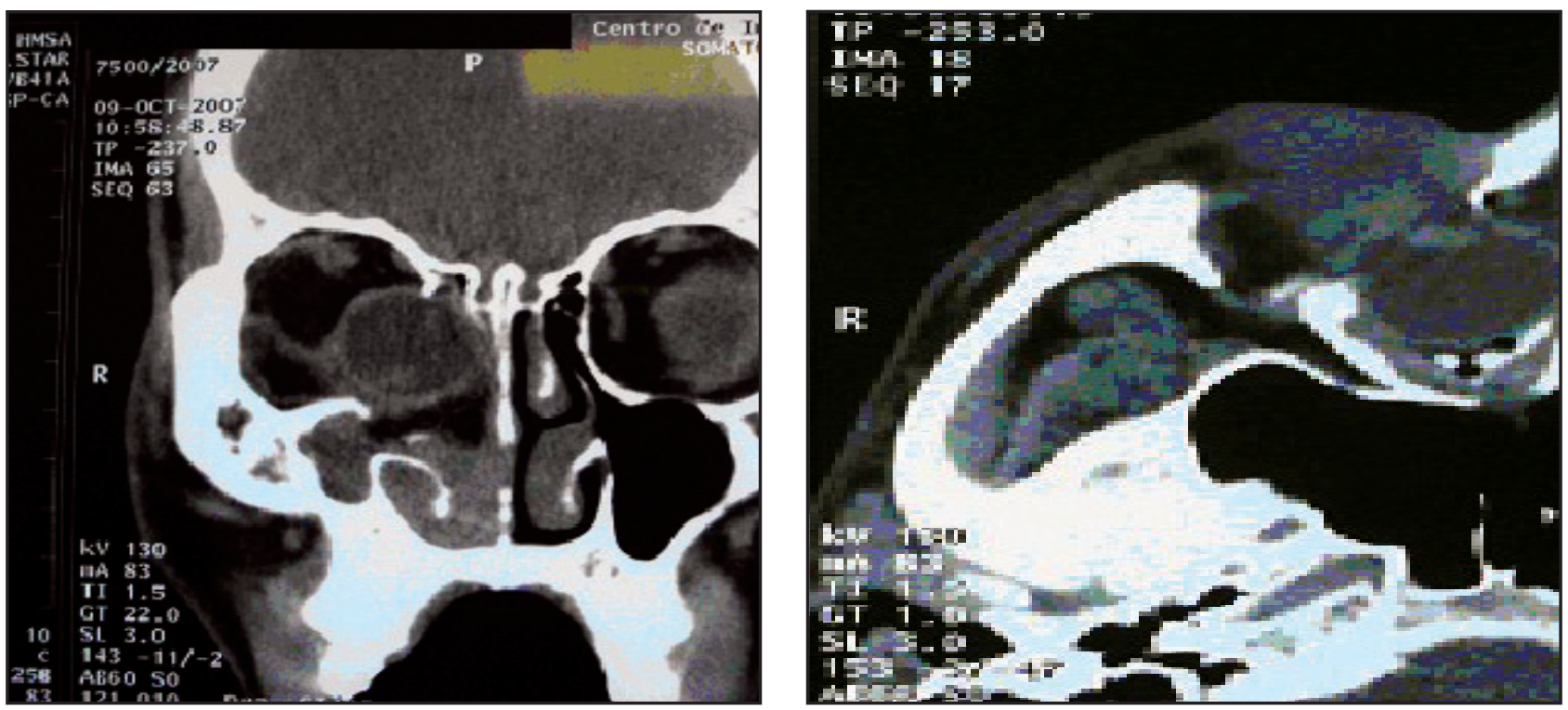

Figure 1: Orbital CT -Coronal and sagital Incidence - Displacement of an intact ocular globe into the maxillary sinus 

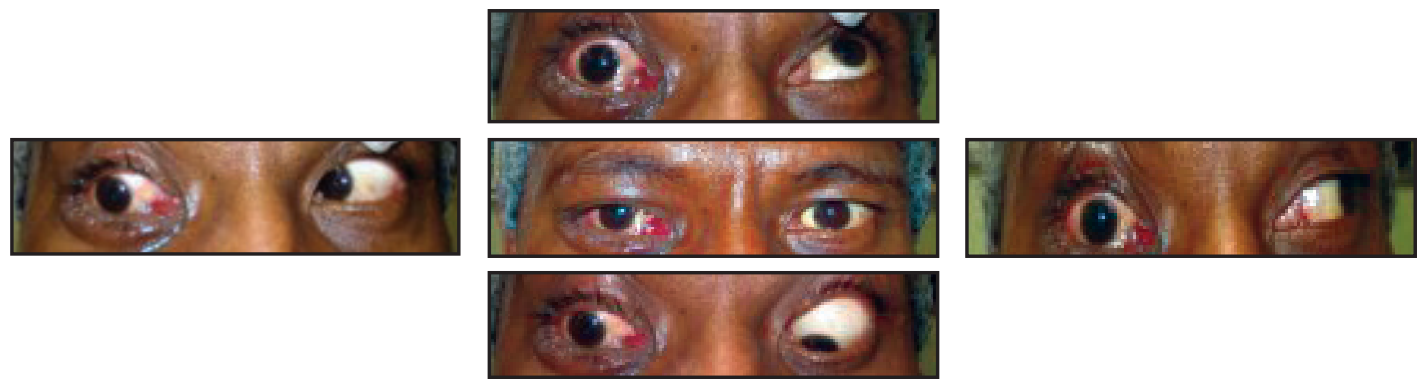

Figure 2: Ocular Motility - Disorders of the right eye movement ( except abduction)

\section{Discussion}

One of the important aspects of the reported case is the rare occurrence of a complete displacement of an intact globe into the maxillary sinus after an extensive blowout fracture.

Only three patients suffering this extreme form of trauma have been reported before by Kim, Berkowitz, and Pelton ${ }^{(5-7)}$. Then, this is the fourth case that reports about a traumatic dislocation of an intact ocular globe into the maxillary sinus and there is one case that reports an ocular displacement to the Antrum ${ }^{(8)}$.

The ocular globe is protected from traumas by the Tenon's capsule, the extra ocular muscles and the orbital fat. In spite of the reports of an intact ocular globe, the ocular motility in most cases is severely restricted, starting at the inferior or medial rectus. The stretching of the rectus muscle fibers near their insertion on the orbital apex may explain the loss of motility when there is no edema or lesion on the extra ocular muscles in the $\mathrm{CT}$ and MRI ${ }^{(1,9)}$.

There are cases reported of long periods of loss of ocular motility with diplopia ${ }^{(10)}$. Considering the immediate surgical treatment to avoid_ischemia of the herniated structures ,it is believed that the loss of motility and the diplopia occur in part because of the edema of the orbital tissues and the injury caused by stretching of the muscular fibers.

\section{Resumo}

Os autores relatam um caso de fratura de assoalho e parede medial de órbita após trauma com deslocamento de globo ocular intacto para o seio maxilar. Os mesmos autores enfatizam o tratamento, complicações e a raridade da entidade. Neste caso o paciente desenvolveu uma boa acuidade visual e uma perda de motilidade ocular como complicação (exceto abdução).

Descritores: Fraturas orbitárias/complicações; Traumatismos oculares/complicações; Relatos de casos

\section{RefERENCES}

1. Furuta M, Yago K, Iida T. Correlation between ocular motility and evaluation of computerized tomography in orbital blowout fracture. Am J Ophthalmol. 2006;142(6):1019-25.

2. He D, Blomquist PH, Ellis E 3rd. Association between ocular injuries and internal orbital fractures. J Oral Maxillofac Surg. 2007;65(4):713-20.

3. Burnstine MA. Clinical recommendations for repair of isolated orbital floor fractures: an evidence-based analysis. Ophthalmology. 2002;109(7):1207-10; discussion 1210-1; quiz 1212-3.

4. Burnstine MA. Clinical recommendations for repair of orbital floor and facial fractures. Curr Opin Ophthalmol. 2003;14(5):236-40.

5. Kim S, Baek S. Traumatic dislocation of the globe into maxillary sinus associated with extra ocular muscle injury. Graefes Arch Clin Exp Ophthalmol. 2005;243(12):1280-3.

6. Berkowitz RA, Putterman AM, Patel DB. Prolapse of the globe into the maxillary sinus after orbital floor fracture. Am J Ophthalmol. 1981;91(2):253-7.

7. Pelton RW, Rainey AM, Lee AG. Traumatic subluxation of the globe into the maxillary sinus. AJNR Am J Neuroradiol. 1998;19(8):1450-1.

8. Ziccardi VB, Patterson GT, Ramasastry S, Sotereanos GC. Management of a severe zygomatic orbital fracture with dislocation of the globe into the antrum. J Craniofac Surg. 1993;4(2):95-101.

9. Jin HR, Lee HS, Yeon JY, Suh MW. Residual diplopia after repair of pure orbital blowout fracture. The importance of extra ocular muscle injury. Am J Rhinol. 2007;21(3):276-80.

10. Antunes-Foschini RM, Bicas HE, Cruz AA. Fratura isolada de parede medial da órbita associada à redução importante de movimentação ocular: relato de caso. Arq Bras Oftalmol. 2002;65(5):567-70. 